\title{
Synchrony in thalamic inputs enhances propagation of activity through cortical layers
}

\author{
Jens Kremkow*1,2, Laurent Perrinet ${ }^{1}$, Arvind Kumar ${ }^{3}$, Ad Aertsen ${ }^{2,4}$ and \\ Guillaume Masson ${ }^{1}$
}

\begin{abstract}
Address: ${ }^{1}$ Institut de Neurosciences Cognitives de la Méditerranée, CNRS \& Aix-Marseille University, Marseille, France, ${ }^{2}$ Neurobiology \& Biophysics, Institute of Biology III, Albert-Ludwigs-University Freiburg, Freiburg, Germany, ${ }^{3}$ Dept. of Neuroscience, Brown University, Providence RI, USA and ${ }^{4}$ Bernstein Center for Computational Neuroscience, Freiburg, Germany

Email: Jens Kremkow* - jens.kremkow@incm.cnrs-mrs.fr

* Corresponding author
\end{abstract}

from Sixteenth Annual Computational Neuroscience Meeting: CNS*2007

Toronto, Canada. 7-12 July 2007

Published: 6 July 2007

BMC Neuroscience 2007, 8(Suppl 2):PI80 doi:I0.1I86/I47I-2202-8-S2-PI80

(C) 2007 Kremkow et al; licensee BioMed Central Ltd.

Sensory input enters the cortex via the thalamocortical (TC) projection, where it elicits large postsynaptic potentials in layer 4 neurons [1]. Interestingly, the TC connections account for only $\sim 15 \%$ of synapses onto these neurons. It has been therefore controversially discussed how thalamic input can drive the cortex. Strong TC synapses have been one suggestion to ensure the strength of the TC projection ("strong-synapse model"). Another possibility is that the excitation from single thalamic fibers are weak but get amplified by recurrent excitatory feedback in layer 4 ("amplifier model"). Bruno and Sakmann [2] recently provided new evidence that individual TC synapses in vivo are weak and only produce small excitatory postsynaptic potentials. However, they suggested that thalamic input can activate the cortex due to the synchronous firing and that cortical amplification is not required. This would support the "synchrony model" proposed by correlation analysis [3].

Here, we studied the effect of correlation in the TC input, with weak synapses, to the responses of a layered cortical network model. The connectivity of the layered network was taken from Binzegger et al. 2004 [4]. The network was simulated using NEST [5] with the Python interface PyNN [6] to enable interoperability with different simulators. The sensory input to layer 4 was modelled by a simple retino-geniculate model of the transformation of light into spike trains [7], which was implemented by leaky integrate-and-fire model neurons.

We found that introducing correlation into TC inputs enhanced the likelihood to produce responses in layer 4 and improved the activity propagation across layers. In addition, we compared the response of the cortical network to different noise conditions and obtained contrast response functions which were in accordance with neurophysiological observations.

\section{Acknowledgements}

Work supported by the 6th RFP of the EU (grant no. I5879-FACETS) and by the BMBF grant $01 \mathrm{GQ} 0420$ to the BCCN Freiburg.

\section{References}

I. Chung S, Ferster D: Strength and orientation tuning of the thalamic input to simple cells revealed by electrically evoked cortical suppression. Neuron 1998, 20:1 I77-1/89.

2. Bruno M, Sakmann B: Cortex is driven by weak but synchronously active thalamocortical synpases. Science 2006, 312:1622-1627.

3. Alonso JM, Usrey WM, Reid RC: Precisely correlated firing in cells of the lateral geniculate nucleus. Nature 1996, 383:8I5-819.

4. Binzegger T, Douglas RJ, Martin KAC: A quantitative map of the circuit of the cat primary visual cortex. J Neurosci 2004, 24:844|-8453.

5. NEST [http://www.nest-initiative.org]

6. PyNN [http://pynn.gforge.inria.fr] 
7. Gazeres N, Borg-Graham LJ, Frégnac Y: A phenomenological model of visually evoked spike trains in cat geniculate nonlagged X-cells. Vis Neurosci 1998, I5: I I57-I I 74.

Publish with Bio Med Central and every scientist can read your work free of charge

"BioMed Central will be the most significant development for disseminating the results of biomedical research in our lifetime. " Sir Paul Nurse, Cancer Research UK

Your research papers will be:

- available free of charge to the entire biomedical community

- peer reviewed and published immediately upon acceptance

- cited in PubMed and archived on PubMed Central

- yours - you keep the copyright

Submit your manuscript here:

http://www.biomedcentral.com/info/publishing_adv.asp 